\title{
The Human T-Cell Leukemia Virus Family, Adult T Cell Leukemia, and AIDS *
}

R.C. Gallo, M. G. Sarngadharan, M. Popovic, J.Schupbach, P. Markham, S.Z. Salahuddin, G. Shaw, F. Wong-Staal, and M.S. Reitz Jr

\section{A. Introduction}

Human T cell leukemia virus (HTLV) is the name by which we have designated a family of related retroviruses from humans. HTLV type I (HTLV-I) is the name we gave the first human retrovirus isolate. HTLV-I is endemic at low rates in different parts of the world, including southern Japan, the Caribbean, South and Central America, the southeastern United States, and especially in Africa. Seroepidemiologic studies show that HTLV-I is the primary etiologic agent of an aggressive form of adult $T$ cell leukemia/lymphoma (ATLL). Infection with HTLV-I in vivo occurs preferentially with $\mathrm{OKT}_{4}{ }^{+} \mathrm{T}$ cells and results in immortalization of the infected cells as well as abrogation of various immune functions of the infected cells, in keeping with its role in the etiology of ATLL. A second related but distinct virus, HTLV type II (HTLV-II), was identified by us in collaboration with $\mathrm{D}$. Golde and colleagues after type I, in material from a patient with hairy cell leukemia. HTLV-II shares many features with HTLV-I, including in vitro transforming activity, but it has been isolated only rarely and has not yet been associated with any disease. A third virus, HTLV type III (HTLV-III), has been isolated many times from individuals who have acquired im-

* Laboratory of Tumor Cell Biology, Developmental Therapeutics Program, Division of Cancer Treatment, National Cancer Institute, Bethesda, MD 20205, USA munodeficiency syndrome (AIDS) or are at risk for this disease. HTLV-III shares some antigenic cross-reactivity with I and II, as well as some general features, including an $\mathrm{OKT}^{+} \mathrm{T}$ cell tropism. The virus is more highly infectious than I or II, however, and has so far shown only cytopathic and not immortalizing effects. Seroepidemiologic data show that HTLV-III is the cause of AIDS.

\section{B. HTLV-I and Adult T Cell Leukemia/ Lymphoma}

The first human retrovirus isolates were obtained from malignant $T$ cell lines established with the use of $T$ cell growth factor (TCGF), a protein present in the media of peripheral blood cells stimulated with phytohemagglutinin $[1,27,40]$. The $\mathrm{T}$ cell lines were established from black patients in the United States with what were diagnosed as unusually aggressive variants of cutaneous $\mathrm{T}$ cell lymphoma $[28,29,35]$. The virus, which we called HTLV-I, has typical retrovirus morphology (Fig. 1) and, like other retroviruses, contains both a reverse transcriptase and high-molecularweight polyadenylated genomic RNA. HTLV-I was shown to be unique by the criteria of protein serology $[14,37,38]$ and nucleic acid hybridization [35], and to be exogenous to man [35]. Transmission is horizontal and does not occur genetically $[9,54]$.

The isolation of HTLV-I made it possible to make antibodies to the viral proteins. These antibodies were then used to test 


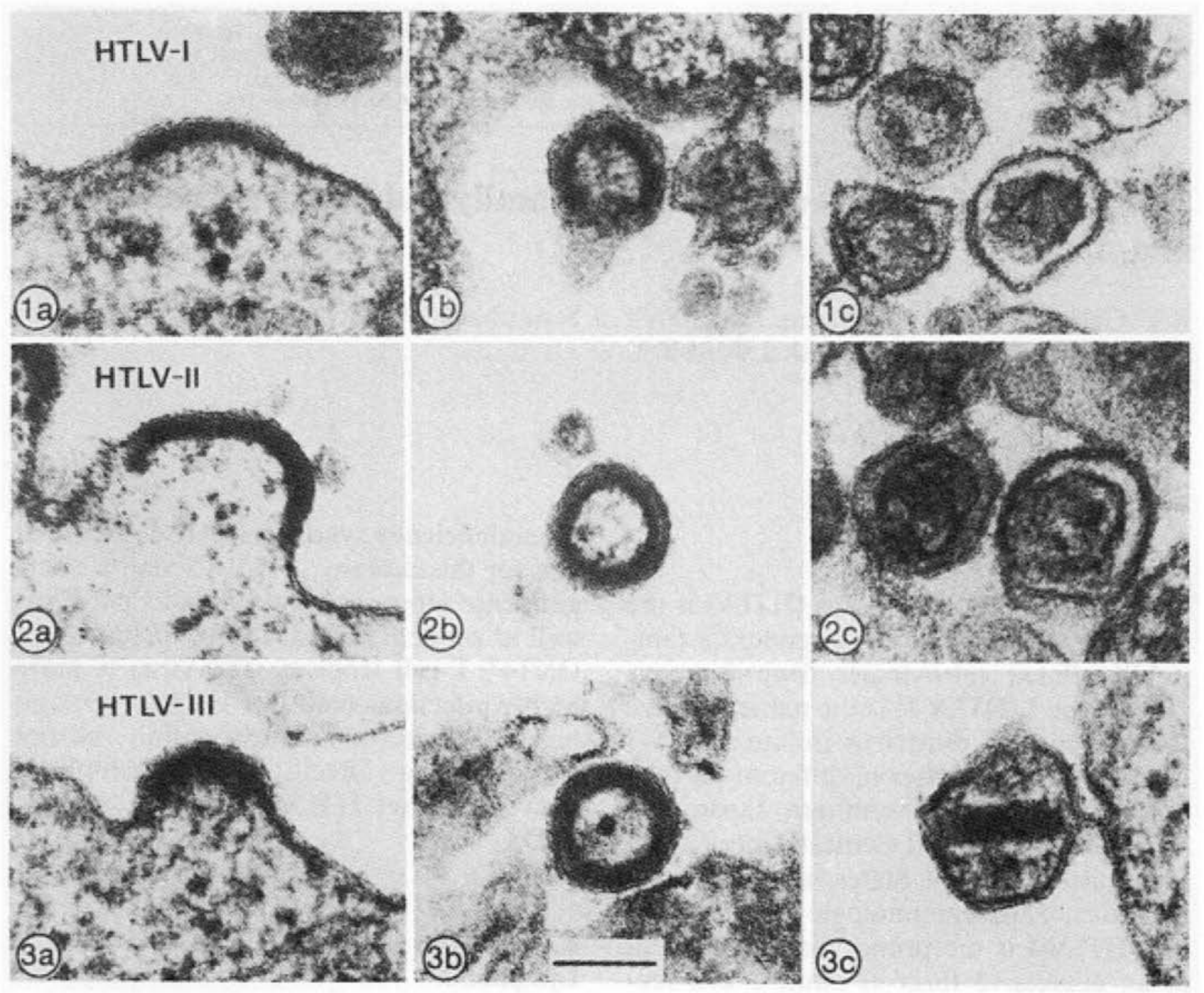

Fig. 1. Electron microscopy of HTLV-I, II, and III. Shown are budding (panels a), immature (panels b), and mature (panels $c$ ) virions of the three types of HTLV. The bar in $3 b$ equals $100 \mathrm{~nm}$

serum samples for the presence of HTLV-I. Most persons in the United States were negative for this virus, including patients with many types of leukemia and lymphoma. HTLV-I was detected in a small fraction of persons from the United States with cutaneous $T$ cell leukemia or lymphoma, most of whom were blacks in the southeastern United States or of Caribbean origin [4, 30]. Even most of these patients were negative.

Two regions of the world were identified, however, in which there were endemic diseases which clinically resembled those from which the first two isolates of HTLV-I were obtained. These regions were the Caribbean [5] and southwestern Japan [51]. The disease in the Caribbean was called lymphosarcoma cell leukemia, and that in Japan was called adult $\mathrm{T}$ cell leukemia; both were found to be closely associated with the presence of HTLV-I by seroepidemiology $[3,13,39]$. Both diseases are now regarded as the same clinical entity, and are collectively called adult $\mathrm{T}$ cell leukemia/lymphoma (ATLL).

Similar results have been reported by investigators in Japan, who also isolated retroviruses from ATLL cell lines [25, 54]. These retroviruses are now known to be isolates of HLTV-I [52]. Sporadic occurrences of both HTLV-I and ATLL have been noted in many other areas of the world [10], and most recently parts of Africa have also been shown to be endemic [43].

As is true for the naturally occurring animal leukemia viruses, only a small fraction of HTLV-I-infected people develop leukemia [50]. It thus appears as though other 
Table 1. Relatedness of HTLV-I, II, and III

\begin{tabular}{llll}
\hline Property & \multicolumn{3}{l}{ Subgroup of HTLV } \\
\cline { 2 - 4 } & $\mathrm{I}$ & $\mathrm{II}$ & $\mathrm{III}$ \\
\hline 1. General infectivity & $\mathrm{Lym}$ & $\mathrm{Lym}$ & $\mathrm{Lym}$ \\
2. Particular tropism & $\mathrm{T} 4$ & $\mathrm{~T} 4$ & $\mathrm{T4}$ \\
3. RT size & $\lambda 100 \mathrm{~K}$ & $\lambda 100 \mathrm{~K}$ & $\lambda 100 \mathrm{~K}$ \\
4. RT divalent cation & $\mathrm{Mg}^{2+}$ & $\mathrm{Mg}^{2+}$ & $\mathrm{Mg}^{2+}$ \\
5. Major core & $\mathrm{p} 24^{24}$ & $\mathrm{p} 24$ & $\mathrm{p}^{24}$ \\
6. Common envelope epitope & + & + & + \\
7. Common p24 epitope & + & + & + \\
8. Nucleic acid homology to I & & \pm & - \\
$\quad$ (stringent) & & & \\
9. Nucleic acid homology to I & & ++ & + \\
$\quad$ (moderate stringency) & & & \\
10. Homology to other retroviruses & 0 & 0 & 0 \\
11. pX & + & + & + \\
12. Produces giant multinucleated cells & + & + & + \\
13. African origin & Likely & $?$ & Likely \\
\hline
\end{tabular}

factors, such as the host immune response, age at exposure, virus dose, or route of infection, may be important factors in determining the end result of infection.

\section{In Vitro Biological Effects of HTLV-I}

HTLV-I was first shown by Miyoshi et al. to transform $T$ cells [26], but the target cells were not shown to be initially free of virus. Subsequently, transformation was achieved using target $\mathrm{T}$ cells shown to be HTLV-I negative $[31,32]$.

HTLV-I is tropic for T cells of the OKT4 ${ }^{+}$ phenotype both in vivo [9] and in vitro [19, $31,32]$. Transmission is achieved easily by co-cultivation with killed virus-producing cells, but only with difficulty when cell-free virus is used. The infected cells take on many of the properties of transformed ATLL cells, including altered morphology, increased growth rate, the tendency to grow in clumps, reduced dependence on TCGF, expression of high levels of the TCGF receptor and HLA-Dr antigens on the cell surface, and (usually) immortalization in culture $[22,23,31,32]$. In vitro transformation by HTLV-I seems to be much more rapid and efficient than leukemogenesis in vitro.

Infection with HTLV-I of functional $T$ cells results in the loss of some or all of their immune functions. For example, a T cell line which was cytotoxic for autologous tumor cells was established from one (rare) long-term survivor of ATLL [22]. These cells were themselves infectable with HTLV-I, and one clone of infected cells was shown to have lost the ability to kill its target cells. Instead, the cell would stop dividing and die when presented with the target [23]. Various other functional losses after infection with HTLV-I have been reported in addition [24, 34]. HTLV-I also infects bone marrow cells in vitro, giving rise to $T$ cell lines of different phenotypes, including $\mathrm{OKT}^{+}{ }^{-} 8^{-}, \mathrm{OKT}^{-} \mathrm{T}^{+}$, and $\mathrm{OKT} 4^{-} 8^{-}$.

\section{HTLV-II}

HTLV-II was originally isolated from a patient with hairy cell leukemia [16]. Although it shares antigenic determinants of the major gag protein, p24, and the envelope proteins $[16,18]$ of HTLV-I, it is readily distinguishable by both protein serology [17] and nucleic acid hybridization [36]. It has many common biochemical properties with HTLV-I (see Table 1), including the ability to transform $T$ cells in vitro and to mediate a loss of immune functions [34]. It has been isolated only twice, and in spite of its biological activity in vitro it is not clear at this time with what disease, if any, it is associated. 

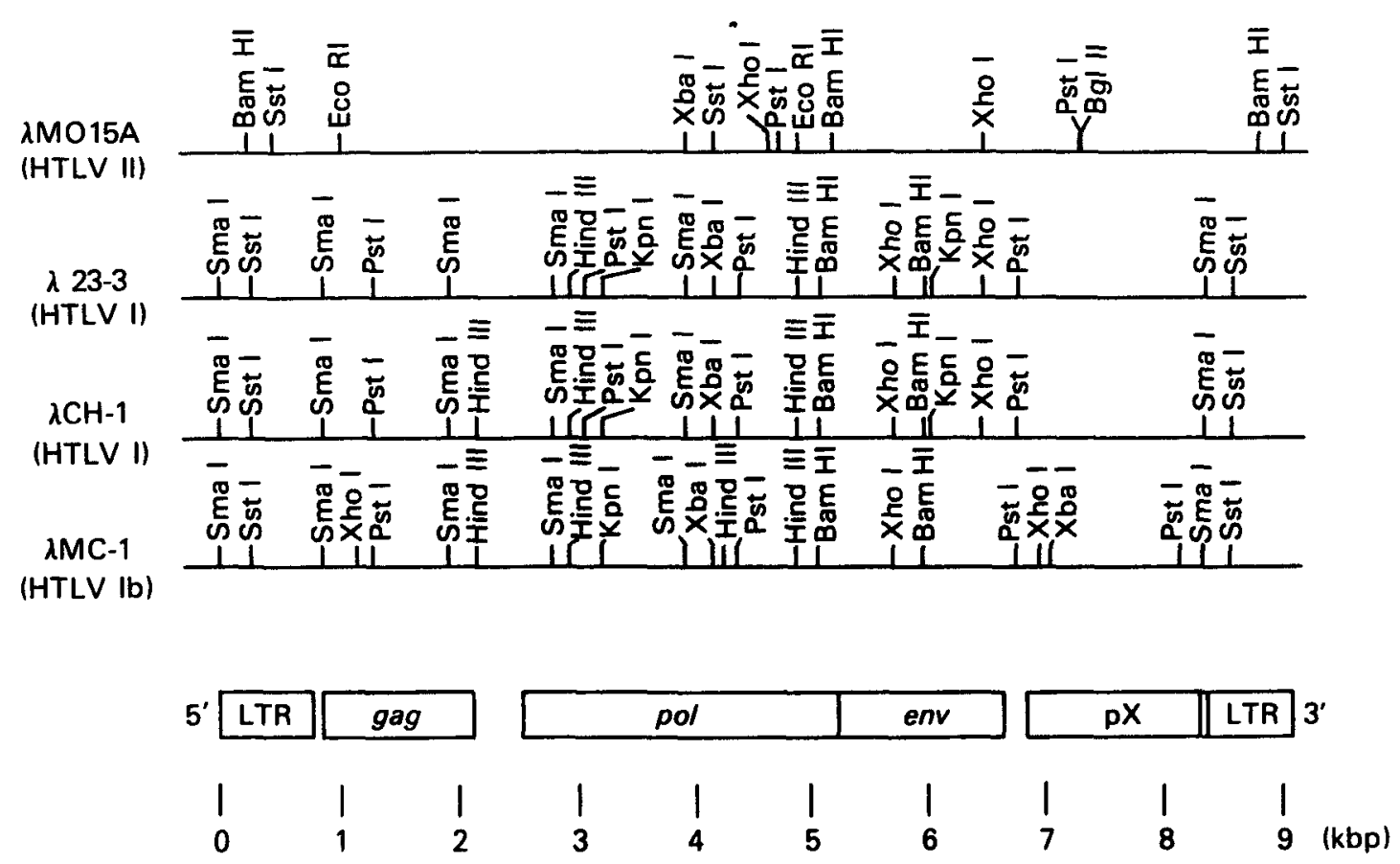

Fig. 2. Genomes and restriction maps of HTLV-I and II. $\lambda \mathrm{MO} 15 \mathrm{~A}$ is an example of HTLV-II, $\lambda 23-$ 3 and $\lambda \mathrm{CH}-1$ are examples of HTLV-1, and $\lambda \mathrm{MC}$ 1 is HTLV-Ib. Genomic regions corresponding to LTR, gag, pol, env, and $\mathrm{pX}$ are drawn to scale according to the published nucleotide sequence of an HTLV-I isolate. Two BglII sites in the $5^{\prime}$ end of $\lambda \mathrm{MO} 15 \mathrm{~A}$ are not shown

\section{E. Genomes of HTLV-I and HTLV-II}

The genome of HTLV-I has been completely sequenced [45]. HTLV-I contains two large terminal repeat (LTR) sequences, in common with other retroviruses, which contain transcriptional control signals. There are fairly typical gag, pol, and env genes, although the gag gene seems to code for three proteins rather than four. In addition, there is an extensive stretch of DNA $3^{\prime}$ to the env gene, which contains several potential open reading frames capable of coding for proteins. This is called the $\mathrm{pX}$ region, and does not seem to be necessary for viral replication. It may be important in cell transformation, as discussed below, but it is not a cell-derived onc gene, since it has no homology with host cell DNA. The structure of the HTLV-I genome is shown in Fig. 2.

The HTLV-II genome also contains a $\mathrm{pX}$ region, and has the same gene order as HTLV-I [46]. Heteroduplex analyses using relaxed hybridization conditions indicate that the two viruses are at least distantly related over the length of their genomes. The $3^{\prime}$ portion of $\mathrm{pX}$ region seems to be the most closely conserved part of the genome. The HTLV-II pX has been recently sequenced [23], and the $3^{\prime}$ part of this sequence has a large open reading frame which has the coding potential for a protein of at least 38 kilodaltons. The close homology with the analogous region of the HTLV-I genome suggests that the product for which these regions code is important for the biological activity of these viruses.

The env gene sequence of HTLV-II has also been recently reported [47], and it also shows significant homology with the HTLV-I env gene, except for the extreme 3' and $5^{\prime}$ termini. The LTRs of the two viruses are markedly different over most of their length [49], but small regions near the RNA cap site, the primer binding site, and a 21base pair sequence present at four copies in the HTLV-II LTR and three copies in the HTLV-I LTR are highly homologous. These last sequences could represent RNA transcriptional enhancers.

How do HTLV-I and II transform T cells? One puzzling aspect of the molecular biology of HTLV-I and II is that although transformation of infected cells is rapid, the viral genome does not contain a typical (i.e., cell-derived) onc gene. Moreover, 
leukemogenesis appears to be relatively inefficient and to involve a long latent period, as with the chronic animal leukemia viruses.

A second puzzling feature of transformation is that the proviral integration site in fresh leukemic blood cells, leukemic cell lines, and cord blood $\mathrm{T}$ cell lines transformed in vitro is nearly always mono- or oligoclonal $[23,53-55]$, suggesting that only a few of the infected cells become transformed. There does not, however, seem to be a preferential integration site common to different leukemic patients or cell lines $[53,55]$, suggesting that a specific integration site is not required for transformation, and that the viral genome itself contains all the necessary information.

What is the reason for these apparent paradoxes? It has been shown that the activities of the HTLV-I and II RNA polymerase promoters are strongly influenced by the cell type in which they are present $[6$, 48], and are far more active in T cells than in other cells. Activity is higher in cells already infected with HTLV than in uninfected cells. This has been interpreted as indicative of the presence of a trans-acting factor present in HTLV-infected cells, which strongly activates the HTLV promoter. Sodroski et al. [48] suggest that this factor may in fact be the $\mathrm{pX}$ product. If this were the case, and if it had the ability to affect the promoters of cellular genes necessary for T cell function and growth, it could help to explain both rapid transformation by HTLV without the requirement for a specific integration site and a cytopathic or dysfunctional effect on infected $T$ cells. It does not explain, however, the monoclonality of transformed cell populations with respect to the viral integration site.

\section{F. HTLV-III and AIDS}

Acquired immunodeficiency syndrome (AIDS) is a recently recognized, generally fatal disease involving helper $\mathrm{T}$ cell depletion and multiple opportunistic infections and/or malignancies. It is prevalent among certain high-risk groups, including promiscuous homosexuals, intravenous drug abusers, hemophiliacs, Haitians, and in- fants born to members of high-risk groups. Because epidemiologic data suggested involvement of a transmissible agent and because of the involvement of OKT4 ${ }^{+} \mathrm{T}$ cells in the disease, it seemed possible that an HTLV-like retrovirus might be involved. Essex et al. reported the presence of an antibody present in a large percentage of AIDS victims and high-risk populations which reacted against a cell surface protein of HTLV-I-infected cells [7, 8].

Recently, we reported on a cell line permissive for the growth of a retrovirus from AIDS and pre-AIDS patients [33]. More than 90 isolates from this group of viruses have been obtained [11; P. Markham et al., in preparation]. Based on morphology, biochemical properties of reverse transcriptase [33], antigenic determinants of env and gag proteins [44], and demonstration of distant but significant nucleic acid homology in the gag-pol region, this new virus is distantly related to HTLV-I and II, and has been designated HTLV-III. A more detailed characterization of HTLV-III is given by Wong-Staal et al. (this volume).

The distant relatedness of these viruses suggests that the antibody activity described by Essex and his colleagues reflected crossreactivity of HTLV-I antigen with antibodies to HTLV-III. We have isolated HTLV-III from a majority of pre-AIDS patients and a large number of actual AIDS patients [11], but isolation from the normal population is rare. Almost all AIDS and pre-AIDS patients have antibodies to HTLV-III [42]. A typical Western blot is shown in Fig. 3. The major reactivity is against a $41 \mathrm{~K}$ protein, which is probably the env antigen of HTLV-III. The most recent data show that the prevalence of such antibodies in these patients is virtually $100 \%$ [41]. The association is so striking as to overwhelmingly suggest that this virus is the cause of AIDS. Recent evidence indicates that the virus called ALV or IDAV, detected previously by Barré-Sinoussi et al. [2], is a member of the same HTLV subgroup.

These accumulated data indicate that there is a group of related human retroviruses with disparate effects on the same target cell, the $\mathrm{OKT}_{4}{ }^{+} \mathrm{T}$ cell. It will be interesting to see whether there are 


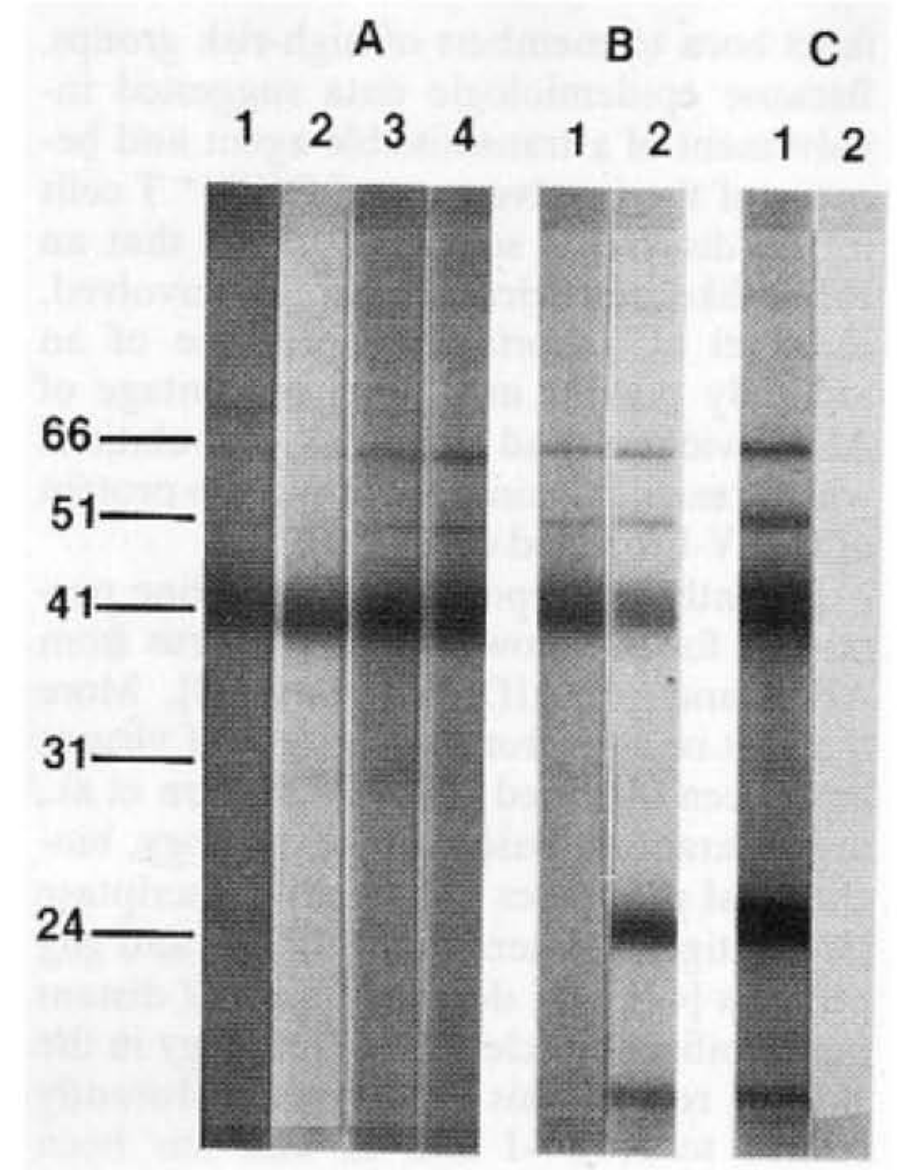

Fig. 3. Analysis of sera for antibodies to HTLVIII by Western blot. $A$, Sera from AIDS patients; $B$ sera from lymphadenopathy patients; $C$ a positive and a negative serum from homosexual subjects. Numbers refer to the molecular weight in kilodaltons

other similar viruses that have yet to be discovered. The identification of the present members of this group gives us opportunities to study T cell biology, as well as the potential to intervene in certain now fatal (and at least in the case of AIDS, increasingly prevalent) $\mathrm{T}$ cell diseases.

\section{References}

1. Arya SK, Gallo RC, Hahn BH, Shaw GM, Popovic M, Salahuddin SZ, Wong-Staal F (1984) Homology of genome of AIDS-associated virus (HTLV-III) with genomes of human T-cell leukemia viruses (HTLV-I and HTLV-II). Science 225:927-930

2. Barré-Sinoussi F, Chermann JC, Rey F, Nugeyre MT, Chamaret S, Gruest J, Dauguet C, Axler-Blin C, Veinet-Brun F, Rouzioux C, Rosenbaum W, Montagnier L (1983) Isolation of a T-lymphotropic retrovirus from a patient at risk for acquired immune deficiency syndrome (AIDS). Science 220:868-870
3. Blattner WA, Kalyanaraman VS, RobertGuroff M, Lister TA, Galton DAG, Sarin PS, Crawford MH, Catovsky D, Greaves M, Gallo RC (1982) The human type-C retrovirus, HTLV, in Blacks from the Caribbean region, and relationship to adult T-cell leukemia/ lymphoma. Int J Cancer 30:257-264

4. Blayney DW, Blattner WA, Robert-Guroff M, Jaffe ES, Fisher RI, Bunn PA Jr, Patton MG, Rarick HR, Gallo RC (1983) The human T-cell leukemia-lymphoma virus in the southeastern United States. JAMA 250: 1048 $-1052$

5. Catovsky D, Greaves MF, Rose M, Galton DAG, Goolden AWG, McCluskey DR, White JM, Lampert I, Bourikas G, Ireland R, Brownell AI, Bridges JM, Blattner WA, Gallo RC (1982) Adult T-cell lymphoma-leukaemia in blacks from the West Indies. Lancet I:639-643

6. Chen ISY, McLaughlin J, Golde DW (1980) Long terminal repeats of human T-cell leukemia virus II genome determine target cell specificity. Nature 309:276-280

7. Essex M, McLane MF, Lee TH, Falk L, Howe CWS, Mullins JI, Cabradilla C, Francis DP (1983a) Antibodies to cell membrane antigens associated with human T-cell leukemia virus in patients with AIDS. Science 220:859-862

8. Essex M, McLane MF, Lee TH, Tachibana N, Mullins JI, Kreiss J, Kasper CK, Poon M-C, Landay A, Stein SF, Francis DP, Cabradilla C, Lawrence DN, Evatt BL (1983b) Antibodies to human T-cell leukemia virus membrane antigens (HTLVMA) in hemophiliacs. Science 221:1061 $-1063$

9. Gallo RC, Mann D, Broder S, Ruscetti FW, Maeda M, Kalyanaraman VS, Robert-Guroff M, Reitz MS (1982) Human T-cell leukemialymphoma virus (HTLV) is in T- but not B-lymphocytes from a patient with cutaneous T-cell lymphoma. Proc Natl Acad Sci USA 79:4680-4684

10. Gallo RC, Kalyanaraman VS, Sarngadharan MG, Sliski A, Vonderheid EC, Maeda M, Nakao Y, Yamada K, Ito Y, Gutensohn N, Murphy S, Bunn PA Jr, Catovsky D, Greaves MF, Blayney DW, Blattner W, Jarrett WFH, zur Hausen $H$, Seligmann $M$, Brouet JC, Haynes BF, Jegasothy BV, Jaffe E, Cossman J, Broder S, Fisher RI, Golde DW, Robert-Guroff M (1983) Association of the human type $\mathrm{C}$ retrovirus with a subset of adult T-cell cancers. Cancer Res 43:3892 $-3899$

11. Gallo RC, Salahuddin SZ, Popovic M, Shearer GM, Kaplan M, Haynes BF, Palker TJ, Redfield R, Oleske J, Safai B, White G, 
Foster P, Markham PD (1984) Frequent detection and isolation of cytopathic retroviruses (HTLV-III) from patients with AIDS and at risk for AIDS. Science 224: 500-503

12. Hahn BH, Shaw GM, Arya SK, Popovic M, Gallo RC, Wong-Staal F (submitted) Molecular cloning and characterization of the virus associated with AIDS (HTLV-III)

13. Haseltine WA, Sodroski J, Patrarca R, Briggs D, Perkins D, Wong-Staal F (1984) Structure of the 3' terminal region of type II human T-lymphotropic virus: Evidence for a new coding region. Science 225:419-421

14. Kalyanaraman VS, Sarngadharan MG, Poiesz BJ, Ruscetti FW, Gallo RC (1981) Immunological properties of a type $C$ retrovirus isolated from cultured human T-lymphoma cells and comparison to other mammalian retroviruses. J Virol 38:906-915

15. Kalyanaraman VS, Sarngadharan MG, Nakao Y, Ito Y, Aoki T, Gallo RC (1982 a) Natural antibodies to the structural core protein (p24) of the human T-cell leukemia (lymphoma) retrovirus found in sera of leukemia patients in Japan. Proc Natl Acad Sci USA 79: 1653-1657

16. Kalyanaraman VS, Sarngadharan MG, Robert-Guroff M, Miyoshi I, Blayney D, Golde D, Gallo RC (1982 b) A new subtype of human T-cell leukemia virus (HTLV-II) associated with a T-cell variant of hairy cell leukemia. Science 218:571-573

17. Kalyanaraman VS, Jarvis-Morar M, Sarngadharan MG, Gallo RC (1984) Immunological characterization of the low molecular weight gag gene proteins p19 and p15 of human T-cell leukemia-lymphoma virus (HTLV) and demonstration of human natural antibodies to them. Virology 132:61-70

18. Lee TH, Coligan JE, McLane MF, Sodroski JG, Popovic M, Wong-Staal F, Gallo RC, Haseltine W, Essex M (in press) Serologic cross-reactivity between envelope gene products of type I and type II human T-cell leukemia virus. Proc Natl Acad Sci USA

19. Mann DL, Popovic M, Murray C, Neuland C, Strong DM, Sarin P, Gallo RC, Blattner WA (1983a) Cell surface antigen expression of newborn cord blood lymphocytes infected with HTLV. J Immunol 131:2021-2024

20. Mann DL, Popovic M, Sarin PS, Murray C, Reitz MS, Strong DM, Haynes BF, Gallo RC, Blattner WA (1983 b) Cell lines producing human $\mathrm{T}$-cell lymphoma virus show altered HLA expression. Nature 305:58-60

21. Markham PD, Salahuddin SZ, Macchi B, Robert-Guroff M, Gallo RC (1984) Transformation of different phenotypic types of hu- man bone marrow T-lymphocytes by HTLVI. Int J Cancer 33:13-17

22. Mitsuya H, Matis LA, Megson M, Bunn PA, Murray C, Mann DL, Gallo RC, Broder S (1983) Generation of an HLA-restricted cytotoxic $T$-cell line reactive against cultured tumor cells from a patient infected with human T-cell leukemia/lymphoma virus. J Exp Med 158:994-999

23. Mitsuya H, Guo H-G, Megson M, Trainor CD, Reitz MS, Broder S (1984) Transformation and cytopathic effect in an immune T-cell clone infected by human T-cell leukemia-lymphoma virus (HTLV). Science 223: 1293-1295

24. Mitsuya H, Guo H-G, Cossman J, Megson M, Reitz M, Broder S (1984) Functional properties of antigen-specific T-cells infected by human T-cell leukemia/lymphoma virus (HTLV-I). Science 225: 1484-1486

25. Miyoshi I, Kubonishi I, Yoshimoto S, Akagi T, Ohtsuki $Y$, Shiraishi $Y$, Nagato $K$, Hinuma Y (1981 a) Type C virus particles in a cord T-cell line derived by co-cultivating normal human cord blood leukocytes and human leukemic T-cells. Nature 294:770 $-771$

26. Miyoshi T, Yoshimoto S, Kubonishi I, Tagushi H, Shiraishi Y, Ohtsuki Y, Akagi T (1981 b) Transformation of normal human cord lymphocytes by co-cultivation with a lethally irradiated human T-cell line carrying type C virus particles. Gann 71: 155-156

27. Morgan DA, Ruscetti FW, Gallo RC (1976) Selective in vitro growth of T-lymphocytes from normal human bone marrow. Science 193: 1007-1008

28. Poiesz BJ, Ruscetti FW, Gazdar AF, Bunn PA, Minna JD, Gallo RC (1980) Detection and isolation of type $\mathrm{C}$ retrovirus particles from fresh and cultured lymphocytes of a patient with cutaneous T-cell lymphoma. Proc Natl Acad Sci USA 77:7415-7419

29. Poiesz BJ, Ruscetti FW, Reitz MS, Kalyanaraman VS, Gallo RC (1981) Isolation of a new type-C retrovirus (HTLV) in primary uncultured cells of a patient with Sézary T-cell leukemia. Nature 294:268-271

30. Posner LE, Robert-Guroff M, Kalyanaraman VS, Poiesz BJ, Ruscetti FW, Fossieck B, Bunn PA Jr, Minna JD, Gallo RC (1981) Natural antibodies to the human $\mathrm{T}$ cell lymphoma virus in patients with cutaneous T cell lymphomas. J Exp Med 154: 333-346

31. Popovic M, Lange-Wantzin G, Sarin PS, Mann D, Gallo RC (1983a) Transformation of human umbilical cord blood $\mathrm{T}$ cells by human T-cell leukemia/lymphoma virus. Proc Natl Acad Sci USA 80:5402-5406 
32. Popovic M, Sarin PS, Robert-Guroff $M$, Kalyanaraman VS, Mann D, Minowada J, Gallo RC (1983b) Isolation and transmission of human retrovirus (human T-cell leukemia virus). Science 219:856-859

33. Popovic M, Sarngadharan MG, Read E, Gallo RC (1984) Detection, isolation, and continuous production of cytopathic retroviruses (HTLV-III) from patients with AIDS and pre-AIDS. Science 224:497-500

34. Popovic M, Flomenberg N, Volkman DJ, Mann D, Fauci AS, Dupont B, Gallo RC (1984) Alteration in T-cell functions by infection with HTLV-I or HTLV-II. Science 226:459-462

35. Reitz MS, Poiesz BJ, Ruscetti FW, Gallo RC (1981) Characterization and distribution of nucleic acid sequences of a novel type $\mathrm{C}$ retrovirus isolated from neoplastic human $T$ lymphocytes. Proc Natl Acad Sci USA 78: 1887-1891

36. Reitz MS Jr, Popovic M, Haynes BF, Clark SC, Gallo RC (1983) Relatedness by nucleic acid hybridization of new isolates of human T-cell leukemia-lymphoma virus (HTLV) and demonstration of provirus in uncultured leukemic blood cells. Virology 126:688-692

37. Rho HM, Poiesz BJ, Ruscetti FW, Gallo RC (1981) Characterization of the reverse transcriptase from a new retrovirus (HTLV) produced by a human cutaneous T-cell lymphoma cell line. Virology 112:355-360

38. Robert-Guroff M, Ruscetti FW, Posner LE, Poiesz BJ, Gallo RC (1981) Detection of the human T-cell lymphoma virus p19 in cells of some patients with cutaneous T-cell lymphoma and leukemia using a monoclonal antibody. J Exp Med 154:1957-1964

39. Robert-Guroff $M$, Nakao $Y$, Notake $K$, Ito Y, Sliski A, Gallo RC (1982) Natural antibodies to human retrovirus HTLV in a cluster of Japanese patients with adult T cell leukemia. Science 215:975-978

40. Ruscetti FW, Morgan DA, Gallo RC (1977) Functional and morphological characterization of human T-cells continuously grown in vitro. J Immunol 119: 131-138

41. Safai B, Sarngadharan MG, Groopman J, Arnett K, Popovic M, Sliski A, Schupbach J, Gallo RC (1984) Seroepidemiological studies of human T-lymphotropic retrovirus type III in acquired immunodeficiency syndrome. Lancet 1: 1438-1440

42. Sarngadharan MG, Popovic M, Bruch L, Schupbach J, Gallo RC (1984) Antibodies reactive with human $\mathrm{T}$-lymphotropic retroviruses (HTLV-III) in the serum of patients with AIDS. Science 224:506-508

43. Saxinger WC, Blattner WA, Levine PH, Clark J, Biggar R, Hoh M, Moghissi J, Ja- cobs $\mathrm{P}$, Wilson $\mathrm{L}$, Jacobson $\mathrm{P}$, Crookes $\mathbf{R}$, Strong M, Ansari AA, Dean AG, Nkrumah FH, Mouvali N, Gallo RC (1984) Human T-cell leukemia virus (HTLV-I) antibodies in Africa. Science 225: 1473-1476

44. Schupbach J, Popovic M, Gilden RV, Gonda MA, Sarngadharan MG, Gallo RC (1984) Serological analysis of a subgroup of human T-lymphotropic retroviruses (HTLV-III) associated with AIDS. Science 224:503-504

45. Seiki M, Hattori S, Hirayama Y, Yoshida M (1983) Human adult T-cell leukemia virus: complete nucleotide sequence of the provirus genome integrated in leukemia cell DNA. Proc Natl Acad Sci USA 80:3618 $-3622$

46. Shaw GM, Gonda MA, Flickinger GH, Hahn BH, Gallo RC, Wong-Staal F (1984) The genomes of evolutionarily divergent members of the human T-cell leukemia virus family (HTLV-I and HTLV-II) are highly conserved, especially in $\mathrm{pX}$. Proc Natl Acad Sci USA 81:4544-4548

47. Sodroski JG, Patarca R, Perkins D, Briggs D, Lee TH, Essex M, Coligan J, Wong-Staal F, Gallo RC, Haseltine WA (1984a) Sequence of the envelope glycoprotein gene of type II human T lymphotropic virus. Science 225: 421-424

48. Sodroski JG, Rosen CA, Haseltine WA (1984b) Trans-acting transcriptional activation of the long terminal repeat of human T-lymphotropic viruses in infected cells. Science 225:381-385

49. Sodroski JG, Trus M, Perkins D, Patarca R, Wong-Staal F, Gelmann E, Gallo R, Haseltine WA (in press) Repetitive structure in the long terminal repeat element of type II human T cell leukemia virus. Proc Natl Acad Sci USA

50. Tajima K, Tominaga S, Suchi T, Kawagoe T, Komoda H, Hinuma Y, Oda T, Fujita K (in press) Epidemiological analysis on distribution of antibody to adult T-cell leukemiavirus-associated antigen (ATLA): possible horizontal transmission of adult T-cell leukemia virus. Gann

51. Takatsuki K, Uchiyama J, Sagawa K, Yodoi J (1977) Adult T-cell leukemia in Japan. In: Seno S, Takaku F, Irino S (eds) Topics in hematology. Excerpta Medica, Amsterdam, pp 73-77

52. Watanabe T, Seiki M, Yoshida M (1984) HTLV type I (U.S. isolate) and ATLV (Japanese isolate) are the same species of human retrovirus. Virology 133:238-241

53. Wong-Staal F, Hahn B, Manzari V, Colombini S, Franchini G, Gelmann EP, Gallo RC (1983) A survey of human leukaemia for se- 
quences of a human retrovirus, HTLV. Nature 302:626-628

54. Yoshida M, Miyoshi I, Hinuma Y (1982) Isolation and characterization of retrovirus from cell lines of human adult T-cell leukemia and its implication in the disease. Proc Natl Acad Sci USA 79:2031-2034
55. Yoshida M, Seiki M, Yamaguchi K, Takatsuki $\mathrm{K}$ (1984) Monoclonal integration of human T-cell leukemia provirus in all primary tumors of adult T-cell leukemia suggests causative role of human T-cell leukemia virus in the disease. Proc Natl Acad Sci USA 81:2534-2537 